\title{
Mesoscale and seasonal variability of community production and respiration in the surface waters of the N.E. Atlantic Ocean
}

\author{
Anne Maixandeau ${ }^{\mathrm{a}}$, Dominique Lefèvre ${ }^{\mathrm{a}, *}$, I.Camila Fernández ${ }^{\mathrm{b}}$, \\ Richard Sempéréa ${ }^{\mathrm{a}}$, Rumi Sohrin ${ }^{\mathrm{a}, \mathrm{c}}$, Joséphine Ras ${ }^{\mathrm{d}}$, France Van Wambeke ${ }^{\mathrm{a}}$, \\ Guy Caniaux ${ }^{\mathrm{e}}$, Bernard Quéguiner ${ }^{\mathrm{b}}$ \\ ${ }^{a}$ Laboratoire de Microbiologie, Géochimie et Ecologie Marines, CNRS/INSU, UMR 6117, Case 901, Centre d'Océanologie de Marseille, \\ Université de la Mediterranée-Campus de Luminy, 13288 Marseille Cedex 9, France \\ ${ }^{\mathrm{b}}$ Laboratoire d'Océanographie et de Biogéochimie, CNRS/INSU, UMR 6535, Case 901, Centre d'Océanologie de Marseille, Université de \\ la Mediterranée-Campus de Luminy, 13288 Marseille Cedex 9, France \\ ${ }^{\mathrm{c}}$ Institute of Geosciences, Shizuoka University, 836 Oya, Shizuoka 422-8529, Japan \\ ${ }^{\mathrm{d}}$ Laboratoire d'Océanographie de Villefranche, Observatoire Océanologique, Chemin du Lazaret BP 28, \\ 06234 Villefranche-sur-Mer Cedex, France \\ Ce
}

\begin{abstract}
Gross community production (GCP) and dark community respiration (DCR) rates were measured in the N.E. Atlantic Basin $\left(38-45^{\circ} \mathrm{N}\right.$ and $\left.15^{\circ} 20^{\prime}-21^{\circ} 20^{\prime} \mathrm{W}\right)$ during the Programme Océanographique Multidisciplinaire MésoEchelle (POMME). Three cruises were conducted over a one-year period (2001), and GCP and DCR were measured at 20 stations using seawater taken from $5 \mathrm{~m}$. In winter, GCP is light limited whereas DCR, which is mainly due to bacteria, is limited by substrate availability. GCP and DCR were under the influence of mesoscale features, with the cyclonic structure enhancing the autotrophy. In spring, light and resource availability remain the major controlling parameters, which are constrained by north-south zonation, rather than mesoscale features. The most productive area is south of $41^{\circ} \mathrm{N}$ at the start of the bloom and is associated with greater DCR as autotrophs contribute to community respiration. The late-summer period is oligotrophic, which contrasts with the previous winter and spring period, characterised by a large quantity of TOC accumulated $(+13.2 \mu \mathrm{M} \mathrm{C}$ from spring to late-summer $)$ and with greater DCR in the southern area. The GCP/DCR ratio greatly varied seasonally, ranging from 0.6 in late summer to 1.3 in
\end{abstract}

\footnotetext{
*Corresponding author. Fax.: + 33491829051.

E-mail address: lefevre@com.univ-mrs.fr (D. Lefèvre).
} 
winter and 2.4 in spring. These results, even restricted to surface ecosystem metabolism $(5 \mathrm{~m})$, strongly suggest that the trophic status of a regional system in the open ocean should be determined over a seasonal cycle.

Keywords: Microbial community; Gross production; Respiration; GCP/DCR ratio; Northeast Atlantic Ocean

\section{Introduction}

In oceanic systems, the balance between gross primary production and community respiration (CR) determines whether the biological pump acts as a net source or sink of carbon (Williams, 1993). Net community production (NCP) is defined as the difference between gross community production (GCP) and CR (Odum, 1971) and provides a direct interpretation of the ocean trophic status (Serret et al., 1999).

The oceanic ecosystem contributes to approximately half of the primary production of the biosphere (Field et al., 1998). However, there is still debate about whether the global open ocean is mainly autotrophic (Williams, 1998; Geider et al., 1997) or heterotrophic (del Giorgio et al., 1997; Duarte and Agusti, 1998; del Giorgio and Duarte, 2002). Regional studies are required to overcome this ambiguity (del Giorgio and Duarte, 2002). This includes the standardisation and comparison of the data sets available for microbial respiration and photosynthesis (González et al., 2002; Serret et al., 2001; Williams and Bowers, 1999; Duarte et al., 1999). Furthermore, the trophic status of an oceanic system evolves over a seasonal cycle from autotrophy to heterotrophy (Sherr and Sherr, 1996). This is a result of the uncoupling between the processes resulting from advective transport or accumulation and consumption of organic matter (Pomeroy and Johannes, 1968; Carlson et al., 1994; Sherr and Sherr, 1996). Respiration rates and primary production exhibit a positive relationship over large spatial scales (del Giorgio and Duarte, 2002). However, on a smaller scale both processes uncouple because of a time lag between GCP and CR (Robinson and Williams, 1999). Temporal and seasonal scales need to be considered in order to define the dominant processes in the oceans over an annual cycle (González et al.,
2001, 2002; Serret et al., 1999, 2002; Arístegui and Harrison, 2002).

The North Atlantic Ocean is the most intense region of $\mathrm{CO}_{2}$ uptake in the global ocean because of the efficiency of the thermodynamic and biological pumps with an approximate net flux of $6-8 \times 10^{12} \mathrm{~g} \mathrm{Ca}^{-1}$ (Takahashi et al., 2002). It is characterised by mesoscale features (Arhan et al., 1994) and an abundant supply of nutrients stimulating ecosystem productivity and making it one of the most biologically productive regions (Rodríguez et al., 2001; Falkowski et al., 1991; McGillicuddy et al., 1998; Oschlies and Garçon, 1998). However, a recent study based on organic matter transport has demonstrated that the North Atlantic basin is metabolically balanced (Hansell et al., 2004). This basin can be divided into several regional systems, which are characterised by heterotrophy in the subtropical gyre area (González et al., 2001, 2002; Robinson et al., 2002; Serret et al., 2002) and by autotrophy in the northern part of the North Atlantic basin (Kiddon et al., 1995; Williams 1998; Serret et al., 1999). Actually, these observations result from the variability of the production and respiration between seasons and regional systems, which we will attempt to quantify in this study through observations from surface data.

This paper addresses a regional study conducted in the N.E. Atlantic Ocean during the Programme océanographique multi disciplinaire méso échelle (POMME). The study area covers the North Atlantic Drift Province (NADR) and the transition zone from the NADR to the warmer and more saline waters of the eastern part of the North Atlantic Subtropical Gyre Province [NAST (E), Longhurst et al., 1995]. This paper highlights the seasonal cycle and mesoscale variability of microbial community production and respiration measured in surface waters $(5 \mathrm{~m})$. To our knowledge, 
this is one of the first reports in which GCP and dark community respiration (DCR) were measured with the same methodology in a seasonal series in the open ocean. The observations were made in relation to the hydrological and hydrodynamic characteristics in order to define the main controlling factors and the influence of mesoscale features on biological processes.

\section{Materials and methods}

This study was carried out during the POMME project in the region between the Azores and Portugal (Fig. 1). This area is characterised by mesoscale eddies and the formation then subduction of modal water. The POMME project consisted of four oceanographic cruises starting in September 2000 (POMME 0) and ending in

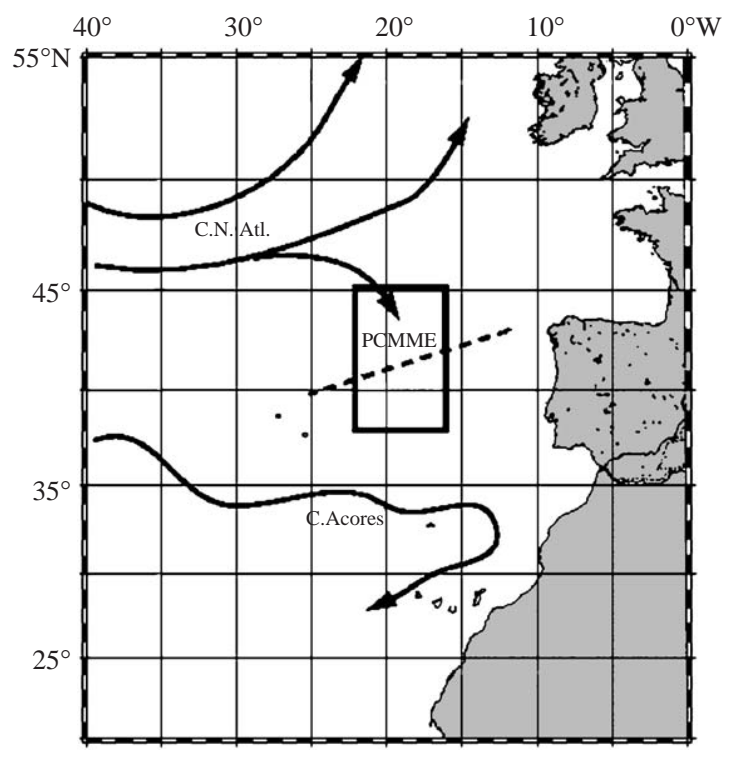

Fig. 1. Study area for the POMME program 2000-2001 in the North Atlantic Ocean. The rectangle represents the study area and the dotted line indicates the approximate zone of discontinuity of the winter mixed layer depth. The investigation consisted of four oceanographic cruises: POMME 0 (17th September-13th October, 2000, not presented here), POMME 1 (leg 1: 2nd February-24th February, leg 2: 27th February 20th March, 2001), POMME 2: (leg 1: 23rd March-13th April, leg 2: 16th April-07th May, 2001) and POMME 3 (leg 1: 23rd August-14th September, leg 2: 17th September-10th October 2001).
September 2001 (POMME 3) (Fig. 1). During leg 1 of each cruise, eulerian sampling was carried out over 20 days at 80 stations (Fig. 1). During leg 2 of each cruise, a lagrangian sampling strategy was carried out in order to study the impact of the hydrological structures on biological processes. This paper is based on the data set from leg 1 of POMME 1, 2 and 3.

Sampling was carried out with a Seabird SBE 9 CTD carousel sampler equipped with $21,12 \mathrm{dm}^{3}-$ Niskin bottles. Prior to the first sampling, the Niskin bottles were cleaned with $0.2 \% \mathrm{HCl}$ and rinsed with distilled water. Rubber O-rings were replaced with Viton and the original rubber tubes replaced with silicon ones to minimise contamination by organic materials.

Rates of GCP, DCR and NCP were estimated from changes in the dissolved oxygen concentration during in vitro incubations. The rates were measured in surface waters (originating from $5 \mathrm{~m}$ ) during leg 1 . Three sets of 4 replicates were collected into $125 \mathrm{~cm}^{3}$-borosilicate glass bottles. One set of samples was fixed immediately to measure the oxygen concentration at time 0 ; the second set was incubated for $24 \mathrm{~h}$ in the dark (DCR); and the remaining set was incubated in $50 \%$ of incident light (NCP), which recreated light conditions from 5 to $20 \mathrm{~m}$ depending on the season, and then fixed. Dissolved oxygen concentration was measured with an automated highprecision Winkler titration system linked to a photometric end-point detector (Williams and Jenkinson, 1982). NCP was calculated as the difference in the dissolved oxygen concentration between "light" incubated samples and "time 0" samples. DCR was calculated as the difference between "dark" incubated samples and "time 0" samples. DCR rates are expressed as a negative $\mathrm{O}_{2}$ flux. GCP was calculated as the difference between NCP and DCR (Gaarder and Gran, 1927). Average of standard deviation (SD) of the quadruplicate analyses of dissolved oxygen concentration was $0.17 \mathrm{mmol} \mathrm{O}_{2} \mathrm{~m}^{-3}, 0.20 \mathrm{mmol} \mathrm{O}_{2} \mathrm{~m}^{-3}$ and $0.23 \mathrm{mmol} \mathrm{O}_{2} \mathrm{~m}^{-3}$ for the samples fixed at "time 0" (T0 samples), the dark incubated samples and the light incubated samples, respectively. Precision of the estimates of DCR, NCP and GCP were obtained as $\pm 0.3 \mathrm{mmol} \mathrm{O}_{2} \mathrm{~m}^{-3} \mathrm{~d}^{-1}$, 
judging from the sum of SD of T0 samples and the dark incubated samples (DCR), T0 samples and the light incubated samples (NCP), and the dark and the light incubated samples (GCP).

Samples for nitrate $\left(\mathrm{NO}_{3}^{-}\right)$analysis were collected into $20 \mathrm{~cm}^{3}$-polyethylene bottles that had been pre-rinsed with $10 \% \mathrm{HCl}$. Samples were analysed immediately with a Technicon Auto Analyser by the protocol of Tréguer and LeCorre (1975).

Samples for total organic carbon (TOC) were collected into pre-combusted glass ampoules directly from the Niskin bottles after being rinsed twice with the sample water. They were immediately acidified with $\mathrm{H}_{3} \mathrm{PO}_{4}$ (final $\mathrm{pH} \sim 2$ ) within a laminar-flow airbench and flame sealed. Samples were kept at $4{ }^{\circ} \mathrm{C}$ in the dark until the analysis. TOC concentration was measured with a modified Shimadzu TOC-5000 (Sempéré et al., 2003). The precision of the analysis was $\pm 1.2 \mu \mathrm{M} \mathrm{C}$ on the mean, estimated from the SD of triple or quadruple analyses of the same sample during the POMME programme (Sohrin and Sempéré, submitted).

Bacterial production was estimated as the incorporated rate of ${ }^{3} \mathrm{H}$-leucine into bacterial cell by the microcentrifugation method (Smith and Azam, 1992) with the Eppendorf ${ }^{\mathrm{TM}}$ techniques detailed in van Wambeke et al. (2002). Samples were incubated with $20 \mathrm{nM}$ (final concentration) leucine and tested for rate saturation. The conversion factor was $1.5 \mathrm{~kg}$ bacterial carbon produced per mole of leucine incorporated (van Wambeke et al., 2002).

Biomass and composition of phytoplankton were estimated from the concentration of chlorophyll $a$ (Tchl $a$ ) and composite pigments assuming that picoplankton $(<2 \mu \mathrm{m})$ contained zeaxanthin and chlorophyll $b$; nanoplankton (2-20 $\mu \mathrm{m})$ contained 19'-butanoyloxyfucoxanthin, 19'-hexanoyloxyfucoxanthin and alloxanthin; and microplankton $(>20 \mu \mathrm{m})$ contained peridinin and fucoxanthin. A volume of $3 \mathrm{dm}^{3}$ of seawater was collected between 0 and $300 \mathrm{~m}$ and filtered through $\mathrm{GF} / \mathrm{F}$ filters. Filters were stored in liquid nitrogen. Pigments were extracted in $3 \mathrm{~cm}^{3}$ of methanol and analysed with an the Agilent 1100 HPLC system, which was coupled to a reverse phase C8 Hypersil
MOS column (dimensions: $3 \times 100 \mathrm{~mm}, 3 \mu \mathrm{m}$ pore size), and a Thermoquest AS3000 autosampler (Claustre et al., in press). Detection limit of pigments was $0.001 \mathrm{mg} \mathrm{m}^{-3}$.

The depth of the euphotic layer (ELD) was calculated from Tchl $a$ profiles and the model developed by Morel and Maritorena (2001), where the Tchl $a$ content in the water column was calculated by integrating Tchl $a$ with depth. ELD was finally determined through an iterative process described in Morel and Berthon (1989). Mixed layer depth (MLD) was defined as by calculating the depth at which the vertical density gradient exceeded $0.002 \mathrm{~kg} \mathrm{~m}^{-3} \mathrm{~m}^{-1}$.

\section{Results}

\subsection{Hydrological context}

During each season the nature and position of identified eddies were determined by the geostrophic current velocity at $50 \mathrm{~m}$ (Fig. 2). It was assumed that the current at $50 \mathrm{~m}$ was representative of the surface current. The observed mesoscale features included several anticyclonic (A1 and A2) and cyclonic (C4) eddies, with a meandering frontal zone located near $41^{\circ} \mathrm{N}$ (Fig. 2), which had been observed previously during an annual cycle (Fernández I. et al., in press). A1 was located in the northern area around $43^{\circ} 30^{\prime} \mathrm{N}, 18^{\circ} \mathrm{W}$ from winter to summer. A2 was located in the southern area at $40^{\circ} \mathrm{N}, 18^{\circ} 50^{\prime} \mathrm{W}$ in winter and at $39^{\circ} 30^{\prime} \mathrm{N}$, $21^{\circ} 30^{\prime} \mathrm{W}$ in spring, but was not identified in late summer. The cyclonic eddy $\mathrm{C} 4$ at $42^{\circ} \mathrm{N}$ moved over the year from 19 to $21^{\circ} \mathrm{W}$.

The sea surface temperature (SST) exhibited a north-south gradient of $4{ }^{\circ} \mathrm{C}$ over the $500 \mathrm{~km}$ of the study area in each season and showed the highest temperatures in the south (Fig. 2). During winter and spring the frontal zone was marked by a SST gradient of $1.5^{\circ} \mathrm{C}$ over $100 \mathrm{~km}$ at $41^{\circ} \mathrm{N}$. C4 was associated with the latitudinal SST gradient and a southward extension of a tongue of cold SST on its eastern side. This structure was apparent during the winter cruise, and remained over the entire period of the study, though to a lesser extent. 


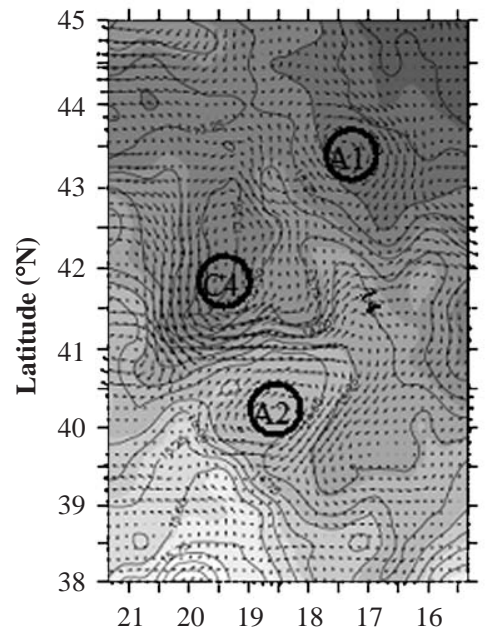

(a)

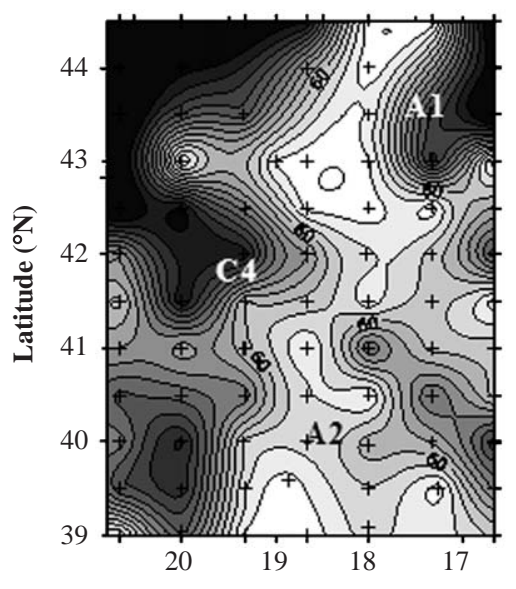

(d)
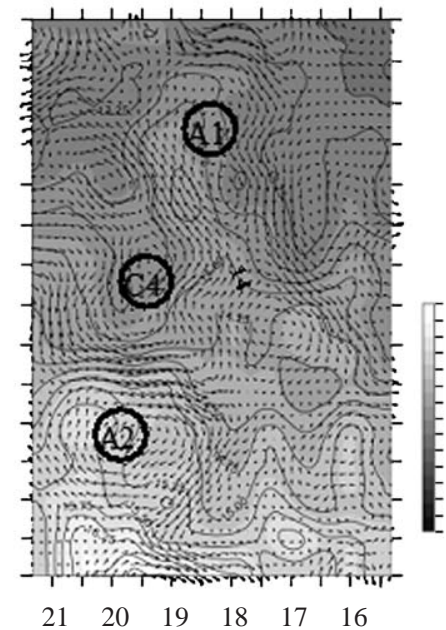

(b)

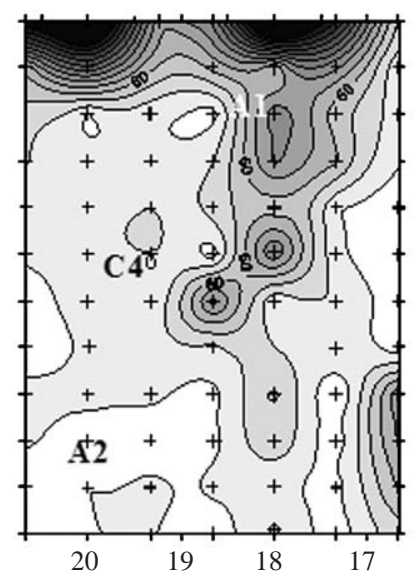

(e)

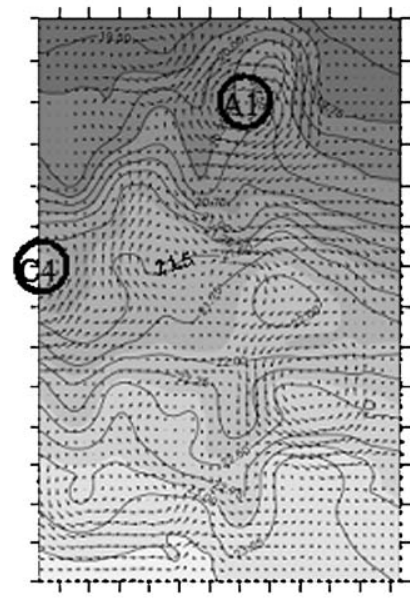

c)

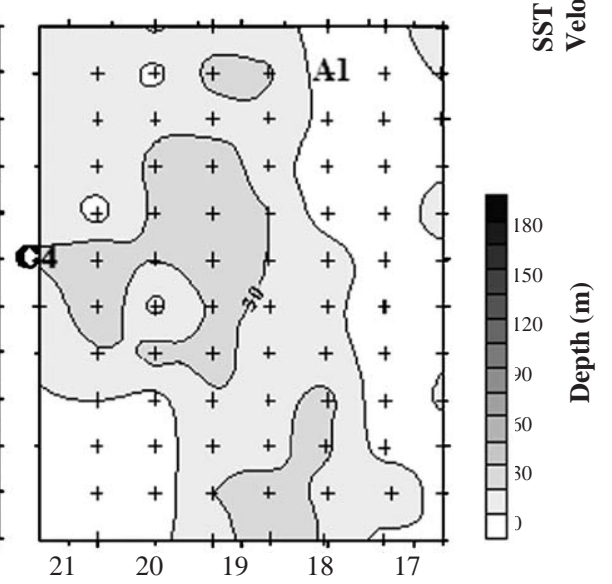

(f)

Fig. 2. Contour plot of sea-surface temperature (SST) at $5 \mathrm{~m}$ and the geostrophic current velocity at $50 \mathrm{~m}$, represented by black arrows (reference: $1 \mathrm{~m} \mathrm{~s}^{-1}$ ) for: (a) winter, (b) spring and (c) late summer. Spatial distribution of the mixed layer depth (MLD, m) for: (d) winter, (e) spring and (f) late summer. MLD is defined by an excess density $>0.002 \mathrm{~kg} \mathrm{~m}^{-3} \mathrm{~m}^{-1}$. A1 and A2 indicate the positions of anticyclonic eddies, and $\mathrm{C} 4$ indicates a cyclonic eddy.

During winter, the MLD ranged from $10 \mathrm{~m}$ to depths greater than $180 \mathrm{~m}$ (Fig. 2). The frontal zone located between $\mathrm{C} 4$ and A2 separated the study area into a northern part, characterised by deeper mixed layers (average depth of $112 \pm 92 \mathrm{~m}$ ), and a southern part with shallower MLD $(74 \pm 53 \mathrm{~m})$. The euphotic layer depth (ELD) was almost constant over the area and averaged $68 \pm 11 \mathrm{~m}$.
During spring, surface currents were stronger and average MLD was shallower than those of winter (Fig. 2). As in winter, the northern area was characterised by a deeper MLD $(59 \pm 67 \mathrm{~m})$ than that in the southern area $(22 \pm 21 \mathrm{~m})$. The ELD did not exhibit a north-south gradient, and the average was $53 \pm 8 \mathrm{~m}$.

During late summer the surface currents weakened and the seasonal thermocline became 
Table 1

Average rates (mean \pm SD) of selected physical, chemical and biological variables at $5 \mathrm{~m}$ in winter, spring and late summer 2001 , for the northern and southern areas separated at $41^{\circ} \mathrm{N}$

\begin{tabular}{|c|c|c|c|c|c|c|}
\hline & \multicolumn{2}{|l|}{ Winter } & \multicolumn{2}{|l|}{ Spring } & \multicolumn{2}{|c|}{ Late Summer } \\
\hline & North & South & North & South & North & South \\
\hline $\operatorname{SST}\left({ }^{\circ} \mathrm{C}\right)$ & $13.3 \pm 0.4$ & $14.6 \pm 0.5$ & $13.6 \pm 0.4$ & $14.9 \pm 0.6$ & $20.8 \pm 0.8$ & $22.5 \pm 0.6$ \\
\hline $\operatorname{MLD}(\mathrm{m})$ & $112 \pm 92$ & $74 \pm 53$ & $59 \pm 67$ & $22 \pm 21$ & $21 \pm 11$ & $20 \pm 11$ \\
\hline $\operatorname{ELD}(\mathrm{m})$ & $69 \pm 12$ & $67 \pm 10$ & $56 \pm 7$ & $48 \pm 7$ & $86 \pm 11$ & $100 \pm 13$ \\
\hline TChl $a\left(\mathrm{mg} \mathrm{m}^{-3}\right)$ & $0.37 \pm 0.15$ & $0.38 \pm 0.14$ & $0.58 \pm 0.18$ & $0.78 \pm 0.28$ & $0.09 \pm 0.03$ & $0.07 \pm 0.02$ \\
\hline $\mathrm{NO}_{3}^{-}(\mu \mathrm{M})$ & $5.52 \pm 0.15$ & $2.81 \pm 1.10$ & $4.55 \pm 1.11$ & $1.69 \pm 1.31$ & $0.04 \pm 0.04$ & $0.04 \pm 0.03$ \\
\hline TOC $(\mu \mathrm{M})$ & $57.8 \pm 3.1$ & $58.5 \pm 2.5$ & $60.9 \pm 4.5$ & $66.2 \pm 5.7$ & $76.8 \pm 3.6$ & $75.4 \pm 5.0$ \\
\hline $\operatorname{GCP}\left(\mathrm{mmol} \mathrm{O} \mathrm{m}^{-3} \mathrm{~d}^{-1}\right)$ & $0.5 \pm 0.4$ & $0.7 \pm 0.6$ & $1.5 \pm 1$ & $3 \pm 1.2$ & $0.6 \pm 0.5$ & $0.6 \pm 0.9$ \\
\hline $\operatorname{DCR}\left(\mathrm{mmol} \mathrm{O} \mathrm{m}^{-3} \mathrm{~d}^{-1}\right)$ & $-0.4 \pm 0.5$ & $-0.5 \pm 0.3$ & $-0.9 \pm 0.7$ & $-1.3 \pm 0.5$ & $-0.8 \pm 0.5$ & $-1.7 \pm 0.9$ \\
\hline $\mathrm{NCP}\left(\mathrm{mmol} \mathrm{O} \mathrm{m}^{-3} \mathrm{~d}^{-1}\right)$ & $0.1 \pm 0.5$ & $0.2 \pm 0.6$ & $0.6 \pm 1.3$ & $1.6 \pm 0.8$ & $-0.2 \pm 0.5$ & $-1.2 \pm 1.1$ \\
\hline $\mathrm{BP}\left(\mathrm{ng} \mathrm{Cdm} \mathrm{dm}^{-3} \mathrm{~h}^{-1}\right)$ & $10.6 \pm 5.1$ & $19.5 \pm 6.1$ & $31.1 \pm 11.4$ & $49.5 \pm 25.9$ & $42.7 \pm 6$ & $37.8 \pm 8.1$ \\
\hline Microplankton (\%) & $7 \pm 2$ & $6 \pm 2$ & $16 \pm 6$ & $15 \pm 8$ & $4 \pm 4$ & $2 \pm 3$ \\
\hline Nanoplankton (\%) & $46 \pm 4$ & $45 \pm 7$ & $61 \pm 10$ & $66 \pm 16$ & $26 \pm 9$ & $20 \pm 7$ \\
\hline Picoplankton (\%) & $47 \pm 6$ & $50 \pm 8$ & $23 \pm 12$ & $20 \pm 13$ & $70 \pm 11$ & $77 \pm 9$ \\
\hline
\end{tabular}

Average rates do not include fluxes at station 25. Microplankton, nanoplankton and picoplankton are expressed as a percentage of contribution to the stock of autotrophic biomass

SST: Sea-surface temperature; MLD: mixed layer depth; ELD: euphotic layer depth; Tchl $a$ : total chlorophyll $a$; TOC: total organic carbon; GCP: gross community production; DCR: dark community production; NCP: net community production, BP: bacterial production. Microplankton, Nanoplankton and Picoplankton are expressed as a percentage of contributions to the stock of auto trophic biomass. Average values do not include fluxes measured at station 25.

shallower, resulting in the masking of the eddy signatures (Fig. 2). The average MLD was $20 \pm 11 \mathrm{~m}$ with no marked difference between the northern and southern parts of the domain (Fig. 2 and Table 1). The shallow MLD was related to atmospheric conditions of the dominant solar heating during this period, which resulted in an increased surface stratification. The average ELD was $92 \pm 14 \mathrm{~m}$ in the whole area.

\section{2. $\mathrm{NO}_{3}^{-}$and $\mathrm{TOC}$}

Nutrient availability in the surface $(5 \mathrm{~m})$ is shown by the $\mathrm{NO}_{3}^{-}$concentrations (Fig. 3). During winter and spring, $\mathrm{NO}_{3}^{-}$values ranged from 1 to $7 \mu \mathrm{M}$. $\mathrm{NO}_{3}^{-}$distribution exhibited a north-south gradient with higher values to the north as mentioned by Fernández (2003). A large decrease in $\mathrm{NO}_{3}^{-}$was observed at $41^{\circ} \mathrm{N}$, especially in the western part of the study area. Around $18^{\circ} 30^{\prime} \mathrm{W}$, lower values spread from $41^{\circ} \mathrm{N}$ to $44^{\circ} \mathrm{N}$, and this was more established in spring. During late summer, $\mathrm{NO}_{3}^{-}$values were below $0.2 \mu \mathrm{M}$ and did not exhibit any spatial pattern. The average $( \pm \mathrm{SD})$ of the surface TOC concentration was $58.0 \pm 3.0$ and $62.9 \pm 5.5 \mu \mathrm{M}$ during winter and spring, respectively (Table 1). The highest surface TOC was observed during late summer with an average of $76.1 \pm 4.4 \mu \mathrm{M}$ as mentioned by Sohrin and Sempéré (in press). Note that the surface TOC did not exhibit a north-south difference during winter or late summer, whereas a significant (two-tailed Student's $t$-test, $p<0.005$ ) difference was found between the northern $\left(41-44.5^{\circ} \mathrm{N}\right.$; $66.2 \pm 5.7 \mu \mathrm{M})$ and southern $\left(39-41^{\circ} \mathrm{N} ; 62.9 \pm\right.$ $5.5 \mu \mathrm{M}$ ) part in spring (Table 1).

\subsection{Biomass and composition of autotrophs}

During winter, Tchl $a$ concentration at $5 \mathrm{~m}$ ranged from 0.1 to $0.6 \mathrm{mg}$ chl $a \mathrm{~m}^{-3}$ (Fig. 3). Centred at $18^{\circ} 40^{\prime} \mathrm{W}$, highest Tchl $a$ values were observed from $39^{\circ} \mathrm{N}$ to $43^{\circ} 30^{\prime} \mathrm{N}$ and were located in the area of $\mathrm{A} 2$ and $\mathrm{C} 4$. Between winter and spring Tchl $a$ increased by a factor of 1.6 in the north and 2.0 in the south (Table 1). During 


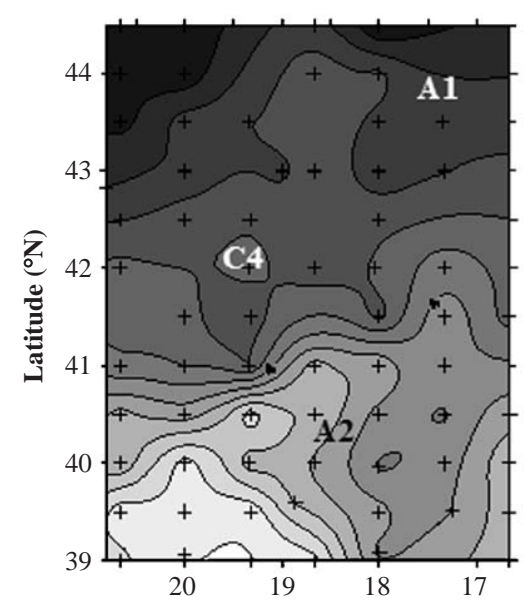

(a)

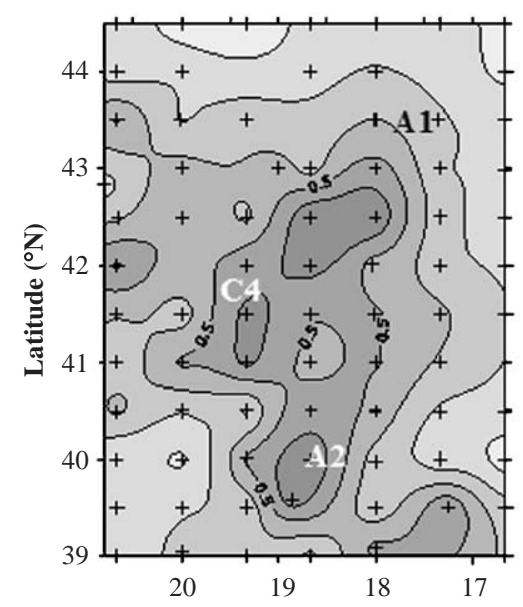

(d)

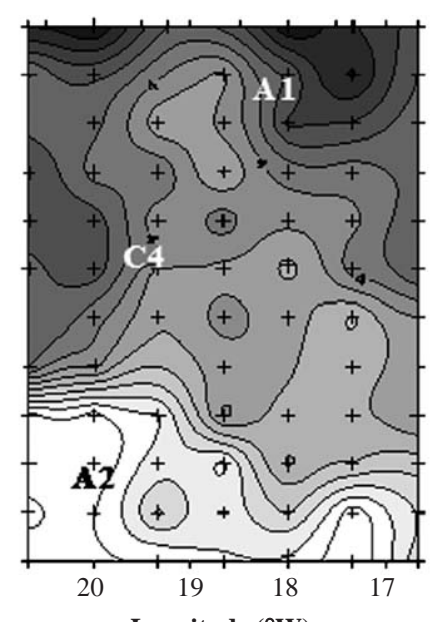

(b)

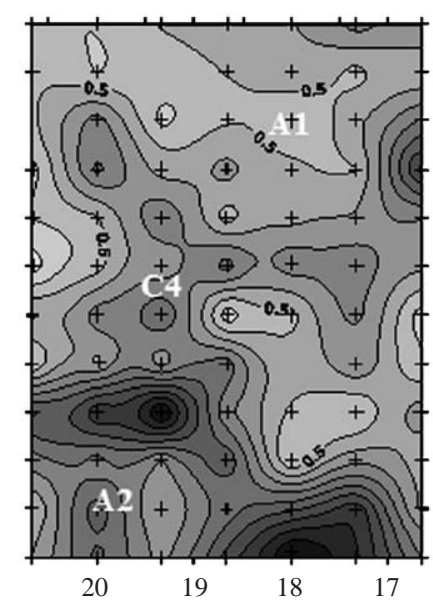

(e)

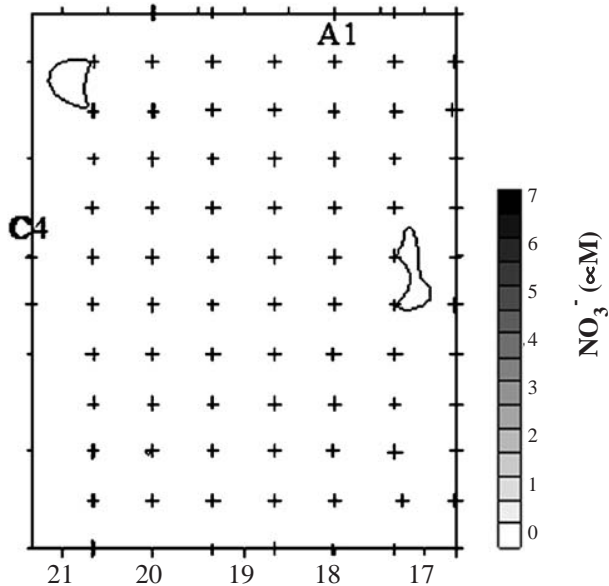

(c)

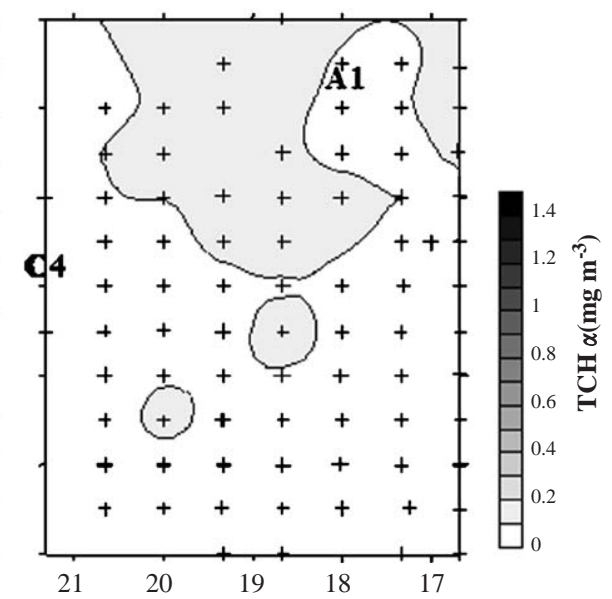

(f)

Fig. 3. Spatial distribution map of $\mathrm{NO}_{3}^{-}$concentrations $(\mu \mathrm{M})$ at $5 \mathrm{~m}$ for: (a) winter, (b) spring and (c) late summer. Spatial distribution of total chlorophyll $a$ concentration (mg. $\mathrm{m}^{-3}$ ) at $5 \mathrm{~m}$ for: (d) winter, (e) spring and (f) late summer. A1 and A2 indicate the positions of anticyclonic eddies, and $\mathrm{C} 4$ indicates a cyclonic eddy.

spring, Tchl $a$ values ranged from 0.4 to $1.5 \mathrm{mg}$ chl $a \mathrm{~m}^{-3}$, with the highest values in the south (Table 1). Tchl $a$ values decreased between spring and late summer by a factor of 6.4 in the north and 11.1 in the south. Late summer values ranged from 0 to $0.14 \mathrm{mg}$ chl $a \mathrm{~m}^{-3}$ and no spatial distribution pattern was observed. During winter, phytoplankton (Table 1) was almost equally composed of nano- and picophytoplankton (46\% and $47 \%$, respectively) with a minor contribution from microphytoplankton (7\%) (Table 1). During spring, the autotrophic community was $15 \%$ microphytoplankton, $64 \%$ nanophytoplankton and $21 \%$ picophytoplankton. By contrast, during late summer, picophytoplankton was the dominant group $(73 \%)$ followed by nanophytoplankton $(24 \%)$ and microphytoplankton $(3 \%)$. There was no evidence of a north-south difference in the composition of autotrophs during the seasonal cycle (Table 1). 


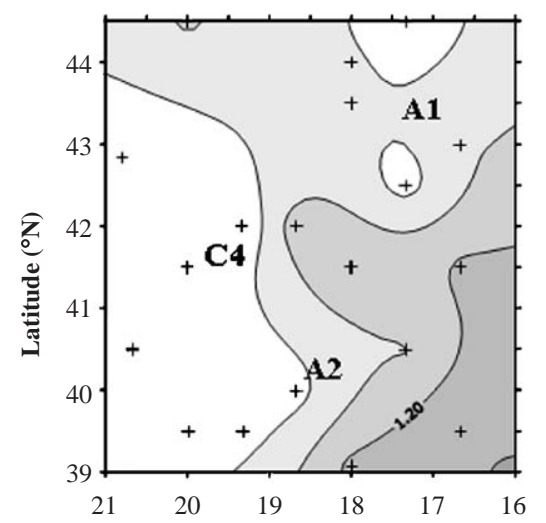

(a)

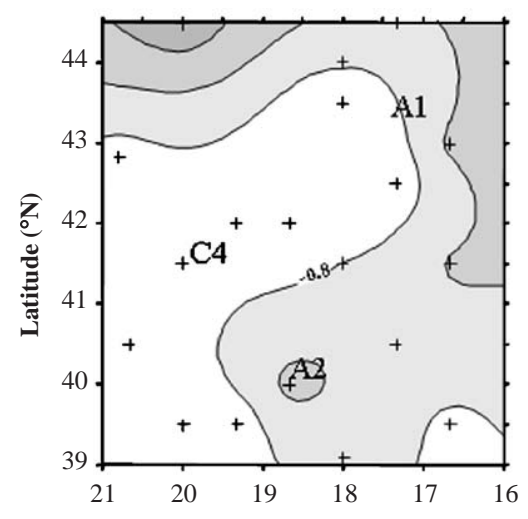

(d)

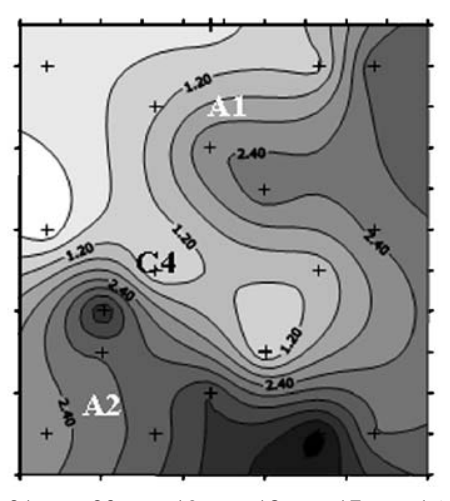

(b)

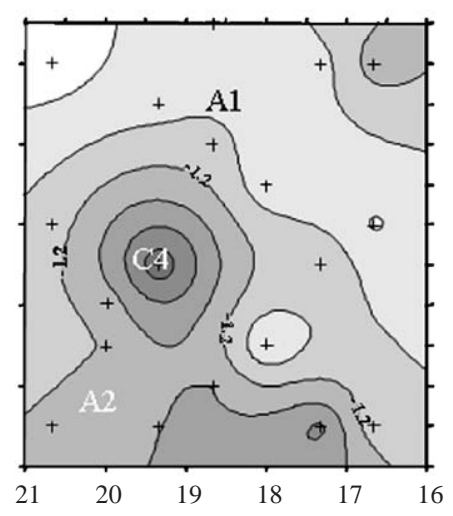

(e)

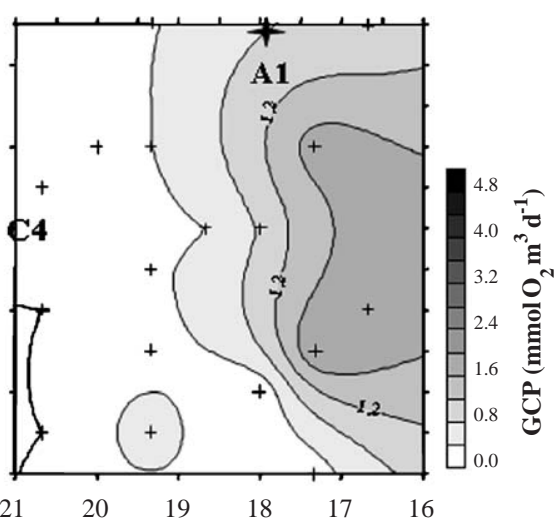

(c)

Fig. 4. Spatial distributions of surface $(5 \mathrm{~m})$ gross community production $\left(\mathrm{GCP}, \mathrm{mmol} \mathrm{O}_{2} \mathrm{~m}^{-3} \mathrm{~d}^{-1}\right)$ for: (a) winter, (b) spring and (c) late summer, and surface $(5 \mathrm{~m})$ dark community respiration (DCR, mmol $\mathrm{O}_{2} \mathrm{~m}^{-3} \mathrm{~d}^{-1}$ ) for: (d) winter, (e) spring and (f) late summer. The stars represent station 25 , located at $18^{\circ} \mathrm{W}-44.5^{\circ} \mathrm{N}$ and characterised by a GCP flux of $6.4 \mathrm{mmol} \mathrm{O}_{2} \mathrm{~m}^{-3} \mathrm{~d}^{-1}$ and DCR flux of $-8.8 \mathrm{mmol} \mathrm{O}_{2} \mathrm{~m}^{-3} \mathrm{~d}^{-1}$. The spatial distributions have been extrapolated excluding this point. A1 and A2 indicate the positions of anticyclonic eddies, and $\mathrm{C} 4$ indicates a cyclonic eddy.

\subsection{GCP in surface water}

GCP at $5 \mathrm{~m}$ exhibited greater variability in the south than in the north, the former characterised by higher GCP (Table 1). Winter GCP ranged from 0 to $2 \mathrm{mmol} \mathrm{O}_{2} \mathrm{~m}^{-3} \mathrm{~d}^{-1}$, averaging $0.6 \pm 0.5 \mathrm{mmol} \mathrm{O}_{2} \mathrm{~m}^{-3} \mathrm{~d}^{-1}$ (Fig. 4); GCP presents a tongue of higher rates extending from the southeast to the northwest in the vicinity of C4. This tongue was also observed for current and SST distributions (Fig. 2). During spring, GCP increased by a factor of 3.7, with rates ranging from 0 to $4.4 \mathrm{mmol} \mathrm{O}_{2} \mathrm{~m}^{-3} \mathrm{~d}^{-1}$ and an average rate of $2.1 \pm 1.3 \mathrm{mmol} \mathrm{O}_{2} \mathrm{~m}^{-3} \mathrm{~d}^{-1}$. The GCP increase was more intensified in the southern area (south of $41^{\circ} \mathrm{N}$ ) where GCP rates increased by a factor of 4.6 as compared to a factor of 2.9 in the north (Table 1). In late summer, GCP decreased by a factor of 3.1 when compared to the spring situation, with an average rate of $0.9 \pm 1.5 \mathrm{mmol} \mathrm{O}_{2} \mathrm{~m}^{-3} \mathrm{~d}^{-1}$. An atypically high rate of $6.4 \mathrm{mmol} \mathrm{O}_{2} \mathrm{~m}^{-3} \mathrm{~d}^{-1}$ was measured at $44.5^{\circ} \mathrm{N}-18^{\circ} \mathrm{W}$ (station 25), which could reflect local environmental conditions. Excluding this high rate, GCP rates ranged from 0 to $1.5 \mathrm{mmol} \mathrm{O}_{2} \mathrm{~m}^{-3} \mathrm{~d}^{-1}$ during late summer with an average of $0.6 \pm 0.7 \mathrm{mmol} \mathrm{O}_{2} \mathrm{~m}^{-3} \mathrm{~d}^{-1}$. The atypicality of station 25, with reference to GCP, is discussed below, in respect of DCR fluxes. 


\subsection{DCR in surface water}

DCR at $5 \mathrm{~m}$ exhibited a lower seasonal variation compared to GCP. However, the north-south difference increased from winter to late summer (Table 1). During winter, DCR ranged from 0 to $-1.4 \mathrm{mmol} \mathrm{O}_{2} \mathrm{~m}^{-3} \mathrm{~d}^{-1}$ with an average rate of $-0.4 \pm 0.4 \mathrm{mmol} \mathrm{O}_{2} \mathrm{~m}^{-3} \mathrm{~d}^{-1}$ (mean $\pm \mathrm{SD}$ ) (Fig. 4). The distribution was almost homogeneous, but somewhat greater rates were found at $\mathrm{A} 2$ in the south. A square of $2.5^{\circ}$ surrounding $\mathrm{C} 4$ was characterised by lower rates, whereas the further extent was characterised by higher rates. During spring, DCR ranged from -0.2 to $-2 \mathrm{mmol}$ $\mathrm{O}_{2} \mathrm{~m}^{-3} \mathrm{~d}^{-1}$ (average, $-1.1 \pm 0.6 \mathrm{mmol} \mathrm{O}_{2} \mathrm{~m}^{-3} \mathrm{~d}^{-1}$ ), and the absolute value increased by a factor of 2.5 compared to that in winter. A marked difference was found between the north and the south: the absolute value of DCR increased by a factor of 2.1 in the north, whereas it increased by a factor of 2.9 in the south (Table 1). During late summer, the average of DCR was $-1.7 \pm 2.0 \mathrm{mmol} \mathrm{O}_{2} \mathrm{~m}^{-3} \mathrm{~d}^{-1}$ and the absolute value increased by a factor of 1.5 compared to that in spring. An atypically large absolute DCR value of $-8.8 \mathrm{mmol} \mathrm{O}_{2} \mathrm{~m}^{-3} \mathrm{~d}^{-1}$ was found at station 25 , which was associated with the high GCP mentioned above. Excluding this atypical rate, the average DCR in late summer was $-0.8 \pm 0.5 \mathrm{mmol} \mathrm{O}_{2} \mathrm{~m}^{-3} \mathrm{~d}^{-1}$ in the north and $-1.7 \pm 0.9 \mathrm{mmol} \mathrm{O} \mathrm{m}^{-3} \mathrm{~d}^{-1}$ in the south.

\section{Discussion}

\subsection{Seasonal cycle}

We found that average surface GCP at $5 \mathrm{~m}$ within the POMME area varied as 0.6, 2.1 and $0.9 \mathrm{mmol} \mathrm{O}_{2} \mathrm{~m}^{-3} \mathrm{~d}^{-1}$ in winter, spring and late summer, respectively, in 2001. These values were lower than the surface GCP $\left(4 \mathrm{mmol} \mathrm{O}_{2} \mathrm{~m}^{-3} \mathrm{~d}^{-1}\right)$ reported by Serret et al. (2001), which they obtained in the same area as ours in June, 1998. However, our GCP rates are higher compared to the surface GCP $\left(0.5 \mathrm{mmol} \mathrm{O}_{2} \mathrm{~m}^{-3} \mathrm{~d}^{-1}\right)$, which they measured in the region further south $\left(27-38^{\circ}\right.$ N) in May-June, 1998 (Fig. 6, Serret et al., 2001). These results are consistent with the temporal and spatial variability of the community production in the N.E. Atlantic as mentioned by González et al. (2002).

GCP and Tchl $a$ exhibited the maximum values in spring (Figs 3 and 4, Table 1). However, the increase in GCP between spring and summer (factor of 3.7) was greater than that in Tchl $a$ (factor of 1.8). On the other hand, $\mathrm{NO}_{3}^{-}$concentration at $5 \mathrm{~m}$ in spring $(3.2 \pm 1.7 \mu \mathrm{M})$ was still close to the winter values $(4.3 \pm 1.1 \mu \mathrm{M})$ (Fig. 3 and Table 1). These $5 \mathrm{~m}$ surface values are consistent with the $50 \mathrm{~m}$ average values of $4.2 \mu \mathrm{M}$ in winter and $3.2 \mu \mathrm{M}$ in spring for $\mathrm{NO}_{3}$ and $0.38 \mathrm{mg} \mathrm{m}^{-3}$ in winter and $0.68 \mathrm{mg} \mathrm{m}^{-3}$ in spring for Tchl a. These results suggest that the $5 \mathrm{~m}$ values are representative of the mixed layer, and also that we conducted the spring observation (March 23-April 13) in the beginning of the bloom. In North Atlantic Bloom Experiment (NABE), the bloom observed in 1989 began on 25 April, and it was triggered by the rapid shallowing of the MLD (Lochte et al., 1993). Tchl $a$ concentration at $5 \mathrm{~m}$ in spring $(0.66 \pm$ $0.25 \mathrm{mg}$ chl $a \mathrm{~m}^{-3}$; Table 1) was lower than those observed during NABE ( $>2 \mathrm{mg} \operatorname{chl} a \mathrm{~m}^{-3}$ at $47^{\circ} \mathrm{N}$; Lochte et al., 1993). This difference also supports the influence that phytoplankton biomass had not yet started to accumulate in our spring observation. Tchl $a$ and GCP decreased from spring to late summer, and the decrease in Tchl $a$ was greater (factor of 9) than that in GCP (factor of 4) (Table 1). As a result, specific community production (community production per unit of Tchl $a$ ) increased from winter to late summer.

Interestingly, the observed autotrophic community structure does not follow the same seasonal evolution, although it tends to be dominated by picoplankton when the system becomes oligotrophic (Cotner and Biddanda, 2002). This implies that productivity is controlled by phytoplanktonic composition associated with hydrodynamical conditions (Lochte et al., 1993; Tarran et al., 2001). Nevertheless, Marañón et al. (2001) have shown that in temperate or oligotrophic environments, the contribution of large phytoplanktonic cells $(>2 \mu \mathrm{m})$ to the total production could be independent of their standing stock, which confirms the major control of hydrodynamics on productivity. 
Previous studies reported that the nutrient level is possibly regulated by hydrodynamical conditions (Lochte et al., 1993; Tarran et al., 2001). Ducklow and Harris (1993) estimated that $2-8 \mu \mathrm{M}$ of $\mathrm{NO}_{3}^{-}$were provided to the upper layer by wintertime convection between $30^{\circ}$ and $50^{\circ} \mathrm{N}$. This observation implies a spatial variability in the initial stock of $\mathrm{NO}_{3}^{-}$in the North Atlantic, which may regulate production and biomass of autotrophs through the year. We found a significant negative correlation $(r=-0.46, n=19, p<0.02)$ between GCP and $\mathrm{NO}_{3}^{-}$in spring and also a negative correlation between GCP and MLD $(r=-0.45, n=19, p<0.05)$. In spring, the area south of $41^{\circ} \mathrm{N}$ was characterised by low $\mathrm{NO}_{3}^{-}$(Fig. 3 ) and high Tchl $a$ and GCP at $5 \mathrm{~m}$ (Figs. 3 and 4), which corresponds to the area of the shallow MLD (Fig. 2). Our results are consistent with Sverdrup (1953), who indicated a strong stratification would result in high GCP and then $\mathrm{NO}_{3}^{-}$depletion. Also, we found that the $5 \mathrm{~m}$ TOC value was higher in the south than in the north in spring, which was associated with higher BP in the south (Table 1). The averaged $50 \mathrm{~m}$ TOC concentrations in spring for the north $(57.0 \mu \mathrm{M})$ and for the south (58.0) are consistent with the observed surface $(5 \mathrm{~m})$ concentrations. These results suggest that relatively vigorous GCP caused the accumulation of TOC, which stimulated BP in the south. We found a significant negative correlation between MLD and Tchl $a$ in winter $(r=-0.41, n=78, p<0.001)$, implying that stability of the surface water and the light availability within the mixed layer would be an important factor controlling autotrophic biomass in winter. On the other hand, there was not a strong correlation between MLD and Tchl $a$ in spring $(r=-0.26, n=80, p<0.02)$, suggesting that the other factors than the stability of the surface water (light intensity, nutrient level or grazing), would have regulated Tchl $a$ in spring.

The seasonal variability in DCR at $5 \mathrm{~m}$ differed from that in GCP: the absolute value of DCR increased from winter to late summer, while GCP was highest in spring (Table 1). The results show that GCP and DCR were seasonally uncoupled at $5 \mathrm{~m}$. Bacterial respiration (BR) was measured at $5 \mathrm{~m}$ during leg 2 of the successive cruises of our study by following oxygen consumption during the incubation experiments on filtered seawater. Average surface BR was $0.41,0.38$ and $0.57 \mathrm{mmol}$ $\mathrm{O}_{2} \mathrm{~m}^{-3} \mathrm{~d}^{-1}$ in winter, spring and late summer, respectively (Lefèvre, unpublished data). BR/DCR ratios averaged 1.0 in winter, 0.34 in spring and 0.71 in late summer. Note that BR was estimated during the exponential growth phase (between days $0-3$ and 4-10) of bacteria growing on DOM, with no grazers, whereas DCR was estimated over $24 \mathrm{~h}$ in unfiltered solution, and mostly BR did not differ significantly from $0 \mathrm{mmol} \mathrm{O}_{2} \mathrm{~m}^{-3} \mathrm{~d}^{-1}$ in the first 1-2 days. Such a methodological difference has a potential to lead to an overestimation of $\mathrm{BR} /$ $\mathrm{DCR}$, but the seasonal trend of BR/DCR can provide qualitative information on the succession of the organisms that mainly contributed to the

Table 2

Correlation between DCR and Tchl $a$, DCR and GCP, DCR and TOC for winter, spring and late summer 2001 in the northern and southern areas separated at $41^{\circ} \mathrm{N}$

\begin{tabular}{|c|c|c|c|c|c|c|c|}
\hline & & \multicolumn{2}{|l|}{ Winter } & \multicolumn{2}{|l|}{ Spring } & \multicolumn{2}{|c|}{ Late summer } \\
\hline & & North & South & North & South & North & South \\
\hline DCR vs. Tchl $a$ & $\begin{array}{l}\mathrm{r} \\
\mathrm{n}\end{array}$ & $\begin{array}{l}-0.68^{*} \\
12\end{array}$ & $\begin{array}{l}0.67 \text { n.s. } \\
7\end{array}$ & $\begin{array}{l}0.59 \text { n.s. } \\
11\end{array}$ & $\begin{array}{l}0.59 \text { n.s. } \\
8\end{array}$ & $\begin{array}{l}-0.21 \text { n.s. } \\
10\end{array}$ & $\begin{array}{l}-0.14 \text { n.s. } \\
8\end{array}$ \\
\hline DCR vs. GCP & $\begin{array}{l}\mathrm{r} \\
\mathrm{n}\end{array}$ & $\begin{array}{l}0.40 \text { n.s. } \\
12\end{array}$ & $\begin{array}{l}0.08 \text { n.s. } \\
7\end{array}$ & $\begin{array}{l}-0.11 \text { n.s. } \\
11\end{array}$ & $\begin{array}{l}0.88^{* *} \\
8\end{array}$ & $\begin{array}{l}0.97 * * * \\
10\end{array}$ & $\begin{array}{l}0.24 \text { n.s. } \\
\text { CO }\end{array}$ \\
\hline DCR vs. TOC & $\begin{array}{l}\mathrm{r} \\
\mathrm{n}\end{array}$ & $\begin{array}{l}-0.79^{*} \\
8\end{array}$ & $\begin{array}{l}-0.86 \text { n.s. } \\
3\end{array}$ & $\begin{array}{l}0.68 \text { n.s. } \\
8\end{array}$ & $\begin{array}{l}0.99^{*} \\
3\end{array}$ & $\begin{array}{l}0.39 \text { n.s. } \\
6\end{array}$ & $\begin{array}{l}-0.84 * \\
7\end{array}$ \\
\hline
\end{tabular}

DCR: dark community production; Tchl $a$ : total chlorophyll $a$; GCP: gross community production; TOC: Total Organic Carbon; n.d.: not determined; n.s.: not significative; *: $p<0.05 ; * *: p<0.01 ; * * * p<0.001$. 
CR. High $B R / D C R$ ratio in winter suggests that bacteria were the main contributor to CR. On the other hand, the lowest BR/DCR ratio was found in spring. We found a significant correlation between DCR and Tchl $a$ in spring $(r=0.60$, $n=19, \quad p<0.01$ ) (Table 2), and these results suggest a significant contribution of the autotrophic community to DCR in spring. In late summer, the contribution of autotrophs to the CR seems to have decreased judging from the $\mathrm{BR} /$ DCR ratio higher than that in spring. Note that TOC had the highest concentrations in late summer, whereas GCP was the highest in spring (Table 1). This may reflect a "time-lag" between transitions of GCP, BR and DCR, the former being the highest in spring, the latter during late summer. Ducklow and Harris (1993) reported that the bacterial bloom followed that of phytoplankton at latitudes between $10^{\circ} \mathrm{N}$ and $60^{\circ} \mathrm{N}$, with a time lag of 10-20 days, implying the possible uncoupling of GCP and BR in the open ocean. Note that previous studies have indicated that the DCR depends on temperature (Lefèvre et al., 1994; Shiah and Ducklow, 1994). However, there was no significant correlation between SST and DCR from winter to late summer in this study. Furthermore, DCR showed a different spatial distribution from that of SST (Figs. 2 and 4). There results indicate that temperature did not significantly control the spatiotemporal variation of DCR in the POMME.

\subsection{Mesoscale variability of biological rates}

Several previous studies have shown that eddies enhance primary production by injection of nutrients into the euphotic layer (Falkowski et al., 1991; McGillicuddy et al., 1998; Oschlies and Garçon, 1998) and by increasing residence time of microorganisms in the euphotic layer by upward motion (Rodríguez et al., 2001). However, the impact of eddies on GCP was not clear in this study (Fig. 4), since production is short-term variable (Arístegui and Harrison, 2002; Karl et al., 2003) and it will be difficult to highlight the relationship between GCP and eddies by the spatial distribution of GCP at $5 \mathrm{~m}$. Indeed, a north-south zonation was observed with GCP in spring $(t=2.9, n=18, p=0.01$, Table 1$)$ with a clear limit at $41^{\circ} \mathrm{N}$ that was characterised by gradients in SST and $\mathrm{NO}_{3}^{-}$(Figs. 2 and 3). Despite the homogeneous composition of the autotrophic community throughout the area (Table 1), the surface water in the southern part seems to be more active in terms of metabolism (higher values of Tchl $a$, GCP, DCR, and BP; see Table 1). If the southern part of the study area had been stratified earlier, then the spring bloom could have been triggered earlier than in the northern area. Therefore, the GCP spatial variability was related to autotrophic biomass accumulation $(r=0.55$, $n=19, p<0.05$ between GCP and Tchl $a$ ).

Since respiration is time variable to a lesser extent than production (Arístegui and Harrison, 2002; Karl et al., 2003), it can be expected that the distribution of DCR is related to mesoscale structures. The cyclonic eddy $\mathrm{C} 4$ is associated with the lowest respiration rate at $5 \mathrm{~m}$, in winter, whereas in spring, $\mathrm{C} 4$ is associated with the highest respiration rate (Fig. 4). The decrease of respiration rate associated with a cyclonic eddy has been previously highlighted in the study of González et al. (2001). The impact of mesoscale structure (cyclonic eddy, frontal zone, etc.) could be considered to be a consequence of divergent horizontal advection (Sherr and Sherr, 1996) associated with the time lag needed to transform the organic matter by bacteria (Carlson et al., 1994; Hoppe et al., 2002), which is in the order of 1-2 weeks (Blight et al., 1995). However, this was not the signal observed at $5 \mathrm{~m}$ in spring. Since we consider that DCR distribution is driven by horizontal advection in winter, the control of DCR spatial variability has changed in spring, probably because (i) the impact of a cyclonic eddy being disrupted by the stratification, as mentioned by McGillicuddy et al. (1999), its impact is explicable for a newly formed cyclone, and (ii) the contribution of autotrophs to CR increased, which should reflect the change in the controlling factor of DCR. The hydrodynamic situation in late summer exhibited a well-established vertical stratification that continues to mask the mesoscale circulation. The results observed for all seasons indicate that GCP did not relate with any mesoscale variability, whereas the absolute values 
of DCR were greater in the southern area ( $t$-test: $n=16, p=0.01$; Table 1).

\section{Conclusion}

Biological rates in surface waters $(5 \mathrm{~m})$ followed a marked seasonal cycle with maximum GCP in spring and maximum DCR in late summer, suggesting that production and respiration are out-of-phase. In winter, the biological fluxes were probably influenced by the mesoscale eddy structure mainly as the vertical motion could control the residence time of cells within the euphotic layer and the horizontal advection of the organic matter. Maximum activities were detected in the southern area (GCP in spring: $3 \pm 1.2 \mathrm{mmol}$ $\mathrm{O}_{2} \mathrm{~m}^{-3} \mathrm{~d}^{-1}$; DCR in late summer: $-1.7 \pm 0.9 \mathrm{mmol}$ $\mathrm{O}_{2} \mathrm{~m}^{-3} \mathrm{~d}^{-1}$ ) below $41^{\circ} \mathrm{N}$, where the spring bloom was observed starting earlier. Over an annual cycle, at $5 \mathrm{~m}$, the balance reached between rates indicated that the upper surface of the POMME area was autotrophic (Fig. 5).

The presented results have highlighted the importance of studying the regional seasonal cycle. The interpretation of surface NCP measurements in term of trophic status of the ecosystem has to be made very cautiously. However, $5 \mathrm{~m}$ NCP observations can reflect the qualitative variability of the ecosystem functioning, which provides information on the temporal variability of the trophic status (Duarte and Agusti, 1998; Williams, 1998; Marañón et al., 2000; González et al., 2001, 2002; del Giorgio and Duarte, 2002). Surface NCP increases from winter to spring (Fig. 5; NCP: $0.12 \pm 0.53 \mathrm{mmol} \mathrm{O}_{2} \mathrm{~m}^{-3} \mathrm{~d}^{-1}$ and $1.02 \pm 1.22 \mathrm{mmol}$ $\mathrm{O}_{2} \mathrm{~m}^{-3} \mathrm{~d}^{-1}$, respectively) and then decreases toward late summer (NCP: $-0.65 \pm 0.95 \mathrm{mmol}$ $\mathrm{O}_{2} \mathrm{~m}^{-3} \mathrm{~d}^{-1}$ and $\mathrm{GCP} / \mathrm{DCR}=0.6$ ). The extrapolation of surface fluxes $(5 \mathrm{~m})$ to the euphotic layer will enable us to investigate the impact of the global oceans' biological pump. Comprehensive sampling is required covering the seasonal cycle in order to take into account the phasing between GCP and DCR, the mesoscale effects on GCP and DCR, the identification of "hot spots" of regional production, and the circulation of resources that sustain low DCR rates on a global scale.
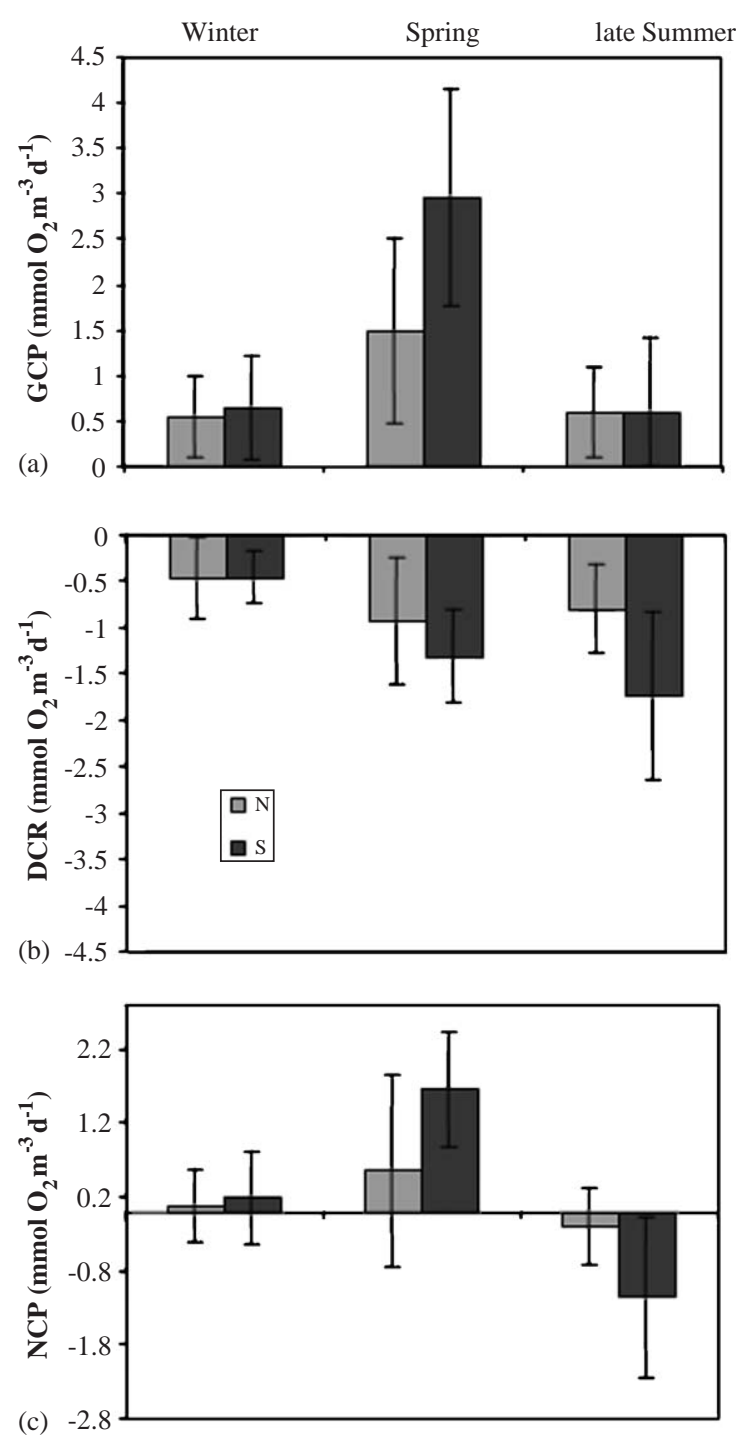

Fig. 5. Mean rates of: (a) gross community production (GCP), (b) dark community respiration (DCR) and (c) net community (NCP) over different seasons (winter, spring, late summer) for the northern (grey rectangle) and southern (black rectangle) areas, which are separated at $41^{\circ} \mathrm{N}$. These calculations do not include fluxes from station 25 .

\section{Acknowledgments}

The authors would like to thank, in particular, L. Dugrais, P. Van Passen and S. Newman for their great help in sampling and subsequent analysis; Drs. L. Mémery and G. Reverdin, leaders 
of the POMME program; the officers and crew of the NO L'Atlante and NO Thalassa for their valuable assistance; and the chief scientists Dr. L. Prieur, M. Bianchi, J.C. Gascard and P. Mayzaud for their guidance. We would like to thank Dr. C. Robinson and Prof. P.J. leB. Williams for their constructive comments. We would like to thank T.L. Bentley for correcting the English. The POMME project is supported by the French programs PATOM and PROOF (CNRS/INSU). We acknowledge 3 anonymous reviewers for their useful and constructive comments, which helped improve the manuscript.

\section{References}

Arhan, M., Colin de Verdière, A., Mémery, L., 1994. The eastern boundary of the subtropical North Atlantic. Journal of Physical Oceanography 24, 1295-1316.

Arístegui, J., Harrison, W.G., 2002. Decoupling of primary production and community respiration in the ocean: implications for regional carbon studies. Aquatic Microbial Ecology 29, 199-209.

Blight, S.P., Bentley, T.L., Lefevre, D., Robinson, C., Rodrigues, R., Rowlands, J., Williams, P.J.1.B., 1995. Phasing of autotrophic and heterotrophic plankton metabolism in a temperate coastal ecosystem. Marine Ecology Progress Series 128, 61-75.

Carlson, C.A., Ducklow, H.W., Michaels, A.F., 1994. Annual flux of dissolved organic carbon from the euphotic zone in the northwestern Sargasso Sea. Nature 371, 405-408.

Claustre, H., Hooker, S., Van Heukelem, L., Berthon, J.F., Barlow, R., Ras, J., Sessions, H., Targa, C., Thomas, C.S., Linde van der, D., Marty, J.C., in press. An intercomparison of HPLC phytoplankton pigment methods using in situ samples: application to remote sensing and database activities. Marine Chemistry.

Cotner, J.B., Biddanda, B.A., 2002. Small players, large role: microbial influence on biogeochemical processes in pelagic aquatic ecosystems. Ecosystems 5, 105-121.

del Giorgio, P.A., Cole Jonathan, J., Cimbleris, A., 1997. Respiration rates in bactéria exceed phytoplankton production in unproductive aquatic systems. Nature 385, 148-151.

del Giorgio, P.A., Duarte, C.M., 2002. Respiration in the open ocean. Nature 420, 379-384.

Duarte, C.M., Agusti, S., 1998. The $\mathrm{CO}_{2}$ balance of unproductive aquatic ecosystems. Science 281, 234-236.

Duarte, C.M., Agusti, S., del Giorgio, P.A., Cole, J.J., 1999. Is the open ocean heterotrophic? Science 284, 1735b.

Ducklow, H.W., Harris, R.P., 1993. Introduction to the JGOFS North Atlantic Bloom Experiment. Deep Sea Research II $40,1-8$.
Falkowski, P.G., Ziemann, D., Kolber, K., Bienfang, P.K., 1991. Role of eddy pumping in enhancing primary production in the ocean. Nature 352, 55-58.

Fernández, I.C., 2003. Cycle de l'azote et production primaire dans l'Atlantique Nord-Est: suivi saisonnier et influence de la méso échelle. Ph.D. Thesis. Université de la Méditerranée-Aix Marseille II, Marseille, France.

Fernández, I.C., Raimbault, P., Caniaux, G., Garcia, N., Rimmelin, P., in press. Impact of mesoscale features on seasonal distribution of nitrate in the Northeast Atlantic Ocean. Journal of Marine Systems.

Field, C.B., Behrenfeld, M.J., Randerson, J.T., Falkowski, P., 1998. Primary production of the biosphere: integrating terrestrial and oceanic components. Science 281, 237-240.

Gaarder, T., Gran, H.H., 1927. Investigations of the Production of Plankton in the Oslo Fjord. Rapport et procès verbaux du Conseil International pour l'Exploration de la Mer 42, 1-48.

Geider, R.J., MacIntyre, H.L., Kana, T.M., 1997. Dynamic model of phytoplankton growth and acclimation: responses of the balanced growth rate and chlorophyll $a$ : carbon ratio to light, nutrient-limitation and temperature. Marine Ecology Progress Series 148, 187-200.

González, N., Anadón, R., Mouriño, B., Sinha, B., Escanez, J., de Armas, D., 2001. The metabolic balance of the planktonic community in the North Atlantic Subtropical Gyre: The role of mesoscale instabilities. Limnology and Oceanography 46 (4), 946-952.

González, N., Anadón, R., Marañón, E., 2002. Large-scale variability of planktonic net community metabolism in the Atlantic Ocean: importance of temporal changes in oligotrophic subtropical waters. Marine Ecology Progress Series 233, 21-30.

Hansell, D.A., Ducklow, H.W., Macdonald, A.M., O’ Neil Baringer, M., 2004. Metabolic poise in the North Atlantic Ocean diagnosed from organic matter transports. Limnology and Oceanography 49, 1084-1094.

Hoppe, H.G., Gocke, K., Koppe, R., Begler, C., 2002. Bacterial growth and primary production along a north-south transect of the Atlantic Ocean. Nature 416.

Karl, D.M., Laws, E.A., Morris, P., Williams, P.J.l., Emerson, S., 2003. Metabolic balance of the open sea. Nature 426, 32.

Kiddon, J., Bender, M.L., Marra, J., 1995. Production and respiration in the 1989 North Atlantic spring bloom: an analysis of irradiance-dependent changes. Deep-sea Research I 42 (4), 553-576.

Lefèvre, D., Bentley, T.L., Robinson, C., Blight, S.P., Williams, P.J.1., 1994. The temperature response of gross and net community production and respiration in time-varying assemblages of temperate marine micro-plankton. Journal of Experimental Marine Biology and Ecology 184, 201-215.

Lochte, K., Ducklow, H.W., Fasham, M.J.R., Stienen, C., 1993. Plankton succession and carbon cycling at $47^{\circ} \mathrm{N} 20^{\circ} \mathrm{W}$ during the JGOFS North Atlantic Bloom Experiment. Deep Sea Research II 40, 91-114.

Longhurst, A., Sathyendranath, S., Platt, T., Caverhill, C., 1995. An estimate of global primary production in the ocean 
from satellite radiometer data. Journal of Plankton Research 17 (6), 1245-1271.

Marañón, E., Holligan, P.M., Varela, M., Mouriño, B., Bale, A.J., 2000. Basin-scale variability of phytoplankton biomass, production and growth in the Atlantic Ocean. DeepSea Research I 47, 825-857.

Marañón, E., Holligan, P.M., Barciela, R., González, N., Mouriño, B., Pazó, M.J., Varela, M., 2001. Patterns of phytoplankton size structure and productivity in contrasting open-ocean environments. Marine Ecology Progress Series 216, 43-56.

McGillicuddy Jr., D.J., Robinson, A.R., Siegel, D.A., Jannasch, H.W., Johnson, R., Dickey, T.D., McNeil, J., Michaels, A.F., Knap, A.H., 1998. Influence of mesoscale eddies on new production in the Sargasso Sea. Nature 394, 263-266.

McGillicuddy Jr., D.J., Johnson, R., Siegel, D.A., Michaels, A.F., Bates, N.R., Knap, A.H., 1999. Mesoscale variations of biogeochemical properties in the Sargasso Sea. Journal of Geophysical Research 104 (NO. C6), 13,381-13,394.

Morel, A., Berthon, J.F., 1989. Surface pigments, algal biomass profiles and potential production of the euphotic layer: relationships reinvestigated in view of remote sensing applications. Limnology and Oceanography 34, 1545-1562.

Morel, A., Maritorena, S., 2001. Bio-optical properties of oceanic waters: a reappraisal. Journal of Geophysical Research 106 (C4), 7163-7180.

Odum, E.P., 1971. Fundamentals of Ecology. Saunders, Philadelphia.

Oschlies, A., Garçon, V., 1998. Eddy-induced enhancement of primary production in a model of the North Atlantic Ocean. Nature 394, 266-269.

Pomeroy, L.R., Johannes, R.E., 1968. Occurrence and respiration of ultraplankton in the upper 500 meters of the ocean. Deep-Sea Research 15, 381-391.

Robinson, C., Serret, P., Tilstone, G., Teira, E., Zubkov, M.V., Rees, A.P., Woodward, E.M.S., 2002. Plankton respiration in the Eastern Atlantic Ocean. Deep-Sea Research I 49, 787-813.

Robinson, C., Williams, P.J.1.B., 1999. Plankton net community production and dark respiration in the Arabian Sea during September 1994. Deep Sea Research II 46, 745-765.

Rodríguez, J., Tintoré, J., Allen, J.T., Blanco, J.M., Gomis, D., Reul, A., Ruiz, J., Rodríguez, V., Echevarría, F., JiménezGómez, F., 2001. Mesoscale vertical motion and the size structure of phytoplankton in the ocean. Nature 410, 360-363.

Sempéré, R., Dafner, E., Allègre, S., Van Wambeke, F., Bianchi, M., Lefèvre, D., Prieur, L., 2003. Total organic carbon distribution and cycling across a geostrophic front in Mediterranean Sea. Implications for the western basin carbon cycle. Journal of Geophysical Research 108 (NO. C11), 3361-3372.

Serret, P., Fernández, E., Sostres, J.A., Anadón, R., 1999. Seasonal compensation of microbial production and re- spiration in a temperate sea. Marine Ecology Progress Series 187, 43-57.

Serret, P., Robinson, C., Fernández, E., Teira, E., Tilstone, G., 2001. Latitudinal variation of the balance between plankton photosynthesis and respiration in the eastern Atlantic Ocean. Limnology and Oceanography 46 (7), 1642-1652.

Serret, P., Fernandez, E., Robinson, C., 2002. Biogeographic differences in the net ecosystem metabolism of the open ocean. Ecology 83 (11), 3225-3234.

Sherr, E.B., Sherr, B.F., 1996. Temporal offset in oceanic production and respiration processes implied by seasonal changes in atmospheric oxygen: the role of heterotrophic microbes. Aquatic Microbial Ecology 11, 91-100.

Shiah, F.K., Ducklow, H.W., 1994. Temperature and substrate regulation of bacterial abundance, production and specific growth rate in Chesapeake Bay, USA. Marine Ecology Progress Series 103, 297-308.

Smith, D.C., Azam, F., 1992. A simple, economical method for measuring bacterial protein synthesis rates in seawater using ${ }^{3}$ H-leucine. Marine Microbial Food Webs 6, 107-114.

Sohrin, R., Sempéré, R. Seasonal variation in total organic carbon in the Northeast Atlantic in 2000-2001. Journal of Geophysical Research, in press.

Sverdrup, H.U., 1953. On conditions for the vernal blooming of phytoplankton. Journalm du Conseil pour l'Exploration de la Mer 18, 287-295.

Takahashi, T., Sutherland, S.C., Sweeney, C., Poisson, A., Metzl, N., Tilbrook, B., Bates, N., Wanninkhof, R., Feely, R.A., Sabine, C., Olafsson, J., Nojiri, Y., 2002. Global Sea-Air $\mathrm{CO}_{2}$ flux based on climatological surface ocean $p \mathrm{CO}_{2}$, and seasonal biological and temperature effects. Deep-Sea Research II 49, 1601-1622.

Tarran, G.A., Zubkov, M.V., Sleigh, M.A., Burkill, P.H., Yallop, M., 2001. Microbial community structure and standing stocks in the NE Atlantic in June and July of 1996. Deep-Sea Research II 48, 963-985.

Tréguer, P., LeCorre, P., 1975. Utilisation de l'AutoAnalyser II Technicon. Second ed. Manuel d'analyse des sels nutritifs dans l'eau de mer, Univ. Bretagne Occidentale, Laboratoire de Chimie marine, Brest, pp. 1-110.

Van Wambeke, F., Christaki, U., Giannakourou, A., Moutin, T., Souvemerzoglou, K., 2002. Longitudinal and vertical trends of bacterial limitation by phosphorus and carbon in the Mediterranean Sea. Microbial Ecology 43 (1), 119-133.

Williams, P.J.1.B., 1993. On the definition of plankton terms. ICES Marine Sciences Symposium 197, 9-19.

Williams, P.J.1.B., 1998. The balance of plankton respiration and photosynthesis in the open oceans. Nature 394, 55-57.

Williams, P.J.1.B., Bowers, D.G., 1999. Regional Carbon Imbalances in the Oceans. Science 284, 1735b.

Williams, P.J.1., Jenkinson, N.W., 1982. A transportable microprocessor-controlled precise Winkler titration suitable for field station and shipboard use. Limnology and Oceanography $27,576-584$. 